\title{
Pengaruh Dukungan Logistik Terpadu di Wilayah Natuna terhadap Kesiapan Operasi KOGABWILHAN I
}

\author{
Andi Mawanto ${ }^{1, *}$ \\ Sekolah Staf dan Komando Angkatan Laut, Jakarta, Indonesia \\ Email : andi.mawanto@tnial.mil.id
}

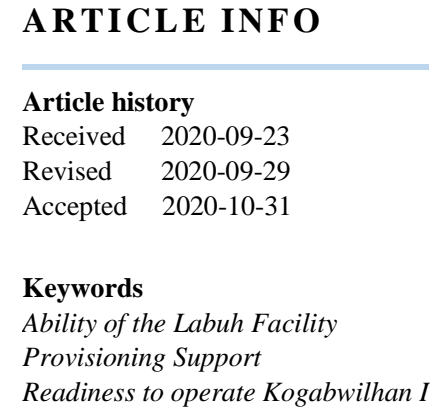

\begin{abstract}
This study aims to test whether the anchoring facilities and provisioning support in the Natuna region are the operational readiness of Kogabwilhan I. The sample in this study were 55 respondents. This type of research is quantitative using Statistical Products and Service Solutions 25 (SPSS 25).

The independent variable in this study is the ability of the anchoring facility and provisioning support, while the dependent variable is the operational readiness of Kogabwilhan I. The results show that the ability of the anchoring facility and provisioning support affects the operational readiness of Kogabwilhan I. This can be seen from the test results that show the variable capability. The anchoring facility $\left(X_{1}\right)$ has a $t$ value of 2,565> $t$ table value at a significance level of 0.05 of 0.200665 with sig $(0.013)<0.05$ and the provisioning support variable $\left(X_{2}\right)$ has a $t$ value of $4.369>t$ value table at a significance level of 0.05 of 0.200665 with sig $0.000<0.05$.
\end{abstract}

\section{A. PENDAHULUAN}

Tentara Nasional Indonesia (TNI) sebagai alat pertahanan negara mempunyai fungsi sebagai penangkal setiap bentuk ancaman militer dan ancaman bersenjata baik yang datang dari luar maupun dari dalam negeri yang mengancam kedaulatan negara, keutuhan wilayah, dan keselamatan bangsa. Untuk melaksanakan fungsi tersebut Panglima TNI membentuk 3 (tiga) Komando Gabungan Wilayah Pertahanan yaitu Kogabwilhan I, II dan III. Dengan dibentuknya kogabwilhan, segala bentuk ancaman militer dan ancaman bersenjata baik yang berasal dari luar maupun dari dalam negeri dapat segera dilaksanakan penindakan secara tegas, cepat dan tepat demi kedaulatan Negara Kesatuan Republik Indonesia. Kogabwilhan I merupakan salah satu bagian dari Kogabwilhan yang berkedudukan di Tanjung Pinang, dipimpin oleh Pati TNI bintang 3 yang saat ini di jabat oleh Pati TNI Angkatan Laut (TNI AL) yang bertugas untuk menjaga kedaulatan negara dengan wilayah laut meliputi perairan di sekitar Sumatera, Kalimantan Barat, Kalimantan Tengah, DKI Jakarta, Jawa Barat, Banten dan Alki I beserta perairan sekitarnya, dalam melaksanakan tugasnya Kogabwilhan mengintegrasikan tugas tiga matra TNI, yakni TNI AL, TNI AU dan TNI $\mathrm{AD}$ dalam bentuk operasi gabungan.

Strategi, logistik dan taktik merupakan satu kesatuan yang tidak bisa dipisahkan dalam melaksanakan suatu operasi. Dukungan logistik terpadu di suatu pangkalan sangat berpengaruh terhadap hasil operasi yang telah di laksanakan. Dukungan logistik terpadu dapat dikelompokkan menjadi 5 (lima) yaitu dukungan pemeliharaan, dukungan perbekalan,dukungan personil, pendidikan dan latihan, serta dukungan fasilitas pangkalan. Pangkalan TNI AL (Lanal) di Natuna merupakan pangkalan aju bagi unsur-unsur TNI AL dalam melaksanakan kegiatan operasi di wilayah perairan Natuna mempunyai tugas pokok menyelenggarakan dukungan tempur, dukungan logistik, dukungan administrasi maupun dukungan khusus bagi unsur-unsur TNI AL (kapal, pesud, dan marinir), melaksanakan operasi, dan melaksanakan pemberdayaan potensi maritim dengan memanfaatkan sarana dan prasarana yang dimiliki pangkalan sendiri maupun instansi yang terkait di wilayahnya.

Potensi sumber daya alam di Laut Natuna yang melimpah dan berbatasan langsung dengan Laut Cina Selatan, merupakan daya tarik kuat bagi banyak negara untuk memanfaatkannya, maraknya penangkapan ikan illegal dan pelanggaran batas wilayah yang dilakukan oleh nelayan asing harus dilaksanakan upaya penegakan hukum yang tegas oleh pemerintah Indonesia. Lanal di Natuna sebagai pangkalan aju di wilayah perairan Natuna mempunyai tugas dalam mendukung 
logistik KRI yang melaksanakan operasi di wilayah tersebut. Tugas Lanal di Natuna dalam mendukung unsur KRI yang melaksanakan operasi di wilayah perairan Natuna mempunyai beberapa kendala yang berdampak tidak optimalnya tugas Lanal, baik tugas pokok maupun tugas tambahan. Keberhasilan TNI Angkatan Laut dalam melaksanakan suatu operasi tidak lepas dari dukungan logistik yang baik dari suatu pangkalan. Dalam penelitian ini, peneliti akan melaksanakan penelitian dengan judul Pengaruh Dukungan Logistik Terpadu di wilayah Natuna guna mendukung kesiapan operasi Kogabwilhan I.

\section{Ruang Lingkup}

Agar lebih fokus dalam melaksanakan penelitian, maka peneliti hanya melaksanakan penelitian tentang kemampuan fasilitas labuh dan dukungan pembekalan di wilayah Natuna guna mendukung kesiapan operasi Kogabwilhan I.

\section{Rumusan Masalah}

Berdasarkan latar belakang permasalahan dan identifikasi masalah yang telah dikemukakan peneliti, maka rumusan masalah penelitian ini adalah bagaimana Pengaruh kemampuan fasilitas labuh dan dukungan pembekalan di wilayah Natuna terhadap kesiapan operasi Kogabwilhan I.

\section{Tujuan Penelitian}

Adapun tujuan yang ingin dicapai dari penelitian ini berdasarkan rumusan masalah adalah untuk menganalisis seberapa besar pengaruh kemampuan fasilitas labuh di wilayah Natuna berpengaruh terhadap kesiapan operasi Kogabwilhan I dan seberapa besar pengaruh dukungan pembekalan di wilayah Natuna berpengaruh terhadap kesiapan operasi Kogabwilhan I.

\section{B. TINJAUAN PUSTAKA}

\section{Teori Produktivitas}

Menurut Cardoso Gomes, Faustino (2000) konsep produktivitas berhubungan dengan efisiensi dan efektivitas. Efisiensi merupakan suatu ukuran perbandingan antara input yang direncanakan dengan input sebenarnya. Sedangkan efektivitas merupakan suatu ukuran yang mengambarkan suatu target yang telah dicapai. Produktivitas tenaga kerja adalah tolak ukur suatu perusahaan dalam mencapai visi dan misinya. Sumber daya manusia dalam suatu perusahaan merupakan elemen strategik organisasi dalam menentukan barang dan jasa yang dihasilkan. Produktivitas kerja dinyatakan tinggi apabila hasil yang diperoleh suatu perusahaan lebih besar daripada sumber daya kerja yang digunakan. Sedangkan produktivitas kerja dinyatakan rendah apabila hasil yang diperoleh suatu perusahaan lebih kecil dari sumber kerja yang digunakan. Peningkatan produktivitas dapat dilihat dalam 3 bentuk yaitu:

a) Jumlah produksi meningkat menggunakan sumber daya yang sama.

b) Jumlah produksi yang sama atau meningkat dicapai dengan menggunakan sumber daya yang lebih sedikit.

c) Jumlah produksi yang jauh lebih besar diperoleh dengan pertambahan sumber daya yang relatif lebih kecil.

Produktivitas yang digunakan dalam peneliti ini adalah ratio perbandingan antara output (keluaran) dengan input (masukan) dimana dengan input yang yang lebih kecil menghasilkan nilai output bertambah dari suatu produk. Perbandingan tersebut tidak hanya dilihat dari segi kuantitas namun juga dilihat dari segi kualitasnya seperti kecepatan dan ketepatan waktu dalam menghasilkan keluaran tersebut. Peneliti menggunakan teori ini dalam pembuatan penelitian untuk mengetahui hasil keluaran dari operasi pengamanan wilayah perairan Natuna dari pengaruh masukan yaitu optimalisasi dukungan logistik terpadu di pangkalan TNI AL di wilayah Natuna.

\section{Teori Logistik}

Teori logistik menurut Henry E. Eccles (1959:315) sesuai buku Logistics in the National Defense menjelaskan hubungan antara Strategi-Logistik-Taktik. Dalam dunia militer, strategi dan logistik sangat terkait menjadi satu kesatuan. Dengan demikian suatu perintah harus melihat strategi dalam kaitannya dengan logistik dan harus melihat logistik dalam kaitannya dengan strategi. Dimana strategi menentukan tujuan dan metode yang luas untuk 
pencapaiannya, taktik menentukan penempatan pasukan secara spesifik untuk mencapai tujuan strategi, logistik menyediakan sarana untuk menciptakan dan mendukung pasukan tempur. Dengan demikian strategi dan taktik memberikan pola penyelenggaraan operasi militer, sedangkan logistik mengadakan sarananya. Strategi dan taktik adalah cara yang digunakan oleh pemimpin untuk mencapai tujuan dari suatu kegiatan militer yaitu memenangkan peperangan. Untuk maksud tersebut selain strategi dan taktik, satu hal yang dominan dan sangat menunjang tercapainya kemenangan adalah dukungan logistik yang memadai bagi personel maupun peralatan yang digunakan. Ketiga unsur tersebut merupakan hal yang tidak dapat dipisahkan karena ketiganya saling mempengaruhi.

\section{Teori Peran Angkatan Laut}

Ken Booth (1997:15) mengatakan bahwa Angkatan Laut di seluruh dunia secara universal memiliki 3 (tiga) peran yang dikenal dengan trinitas peran Angkatan Laut, antara lain:

a) Peran Militer (military role). Pada hakikatnya adalah penggunaan kekuatan secara optimal untuk memenangkan perang atau konflik bersenjata. Penggunaan kekuatan tersebut dilaksanakan dalam rangka penegakan kedaulatan negara di laut dengan cara pertahanan negara dan penangkalan melalui penyiapan kekuatan untuk perang, menangkal setiap ancaman militer melalui laut, menjaga stabilitas kawasan maritim, melindungi, dan menjaga perbatasan laut dengan negara tetangga.

b) Peran Polisionil (Constabulary role). Dilaksanakan dalam rangka menegakkan hukum di laut, melindungi sumber daya dan kekayaan laut nasional, memelihara ketertiban di laut serta mendukung pembangunan bangsa dengan memberikan kontribusi terhadap stabilitas dan pembangunan nasional.

c) Peran Diplomasi (Diplomacy role). Peran ini bagi setiap Angkatan Laut di seluruh dunia dilaksanakan dengan menggunakan kekuatan laut sebagai sarana diplomasi dalam mendukung kebijakan luar negeri pemerintah dan dirancang untuk memengaruhi kepemimpinan negara atau beberapa negara dalam keadaan damai atau pada situasi bermusuhan.

\section{Hipotesis}

Menurut Silaen, Sofar (2013:59) bahwa perumusan hipotesis diawali dengan pemahaman masalah penelitian secara saksama dan masalah dirumuskan dengan baik, lalu merumuskan anggapan dasar, kemudian membuat suatu teori sementara yang kebenarannya masih perlu diuji. Hipotesis awal yang dibuat peneliti terhadap hubungan antar variabel adalah sebagai berikut:

a) $\mathrm{H}_{0}=$ Tidak terdapat pengaruh yang signifikan kemampuan fasilitas labuh di wilayah Natuna terhadap kesiapan operasi Kogabwilhan I.

$\mathrm{H}_{1}=$ Terdapat pengaruh yang signifikan kemampuan fasilitas labuh di wilayah Natuna terhadap kesiapan operasi Kogabwilhan I.

b) $\mathrm{H}_{0}=$ Tidak terdapat pengaruh yang signifikan dukungan pembekalan di wilayah Natuna terhadap kesiapan operasi Kogabwilhan I.

$\mathrm{H}_{1}=$ Terdapat pengaruh yang signifikan dukungan pembekalan di wilayah Natuna terhadap kesiapan operasi Kogabwilhan I.

\section{METODOLOGI PENELITIAN}

\section{Metode Penelitian}

Metode penelitian yang paling baik menurut Sugiyono (2014:104) adalah yang efektif dan efisien, yaitu metode penelitian yang dapat menghasilkan informasi yang lengkap dan valid, dilakukan dengan cepat, sehingga dapat menghemat biaya, tenaga dan waktu. Metode penelitian yang di gunakan dalam penelitian kuantitatif ini adalah metode survey. Neolaka, Amos (2010:17) berpendapat bahwa penelitian yang bersifat survei atau penelitian survei adalah penelitian yang dilakukan pada populasi besar maupun kecil, tetapi data yang dipelajari adalah data dari sampel yang diambil dari populasi tersebut, sehingga ditemukan kejadiankejadian relatif, distribusi, dan hubungan-hubungan antar-variabel. Penelitian ini difokuskan 
untuk melihat hubungan antar variabel bebas yaitu pengaruh kemampuan fasilitas labuh $\left(\mathrm{X}_{1}\right)$ dan dukungan pembekalan $\left(\mathrm{X}_{2}\right)$, terhadap variabel terikat yaitu Operasi Kogabwilhan I (Y).

\section{Populasi dan Sampel}

Populasi penelitian ini adalah personel Staf Operasi, Patroli Keamanan, Posal adan Staf Administrasi Logistik di wilayah Natuna.

Pengambilan sampel harus dilakukan sedemikian rupa sehingga diperoleh sampel yang benar-benar dapat mewakili dan dapat menggambarkan keadaan populasi yang sebenarnya. Besaran sampel dalam penelitian ini menggunakan rumus Slovin adalah sebagai berikut:

$$
\mathrm{n}=\frac{\mathrm{N}}{1+\mathrm{N}(\mathrm{e})^{2}}
$$

Keterangan:

$\mathrm{n}=$ Ukuran sampel/jumlah responden

$\mathrm{N}=$ Ukuran Populasi

$\mathrm{e}=$ presentase kelonggaran ketelitian kesalahan pengambilan sampel yang bisa ditolerir, $\mathrm{e}=0,1$

Besaran sampel yang diambil adalah sebagai berikut:

$$
\mathrm{n}=\frac{\mathrm{N}}{1+\mathrm{N}(\mathrm{e})^{2}} \quad=\frac{107}{1+107(0,1)^{2}} \quad=51,69 \text { disesuaikan menjadi } 55 \text { responden } \text {. }
$$

\section{Sumber Data}

Arikunto, Suharsimi (2013:115) mengatakan bahwa Sumber data dalam penelitian adalah subjek dari mana data dapat diperoleh yaitu person (orang), place (tempat) dan paper (kertas/tulisan/simbol). Sumber data primer diambil langsung dari pangkalan di wilayah Natuna berupa kuesioner yang disebarkan kepada subjek penelitiian dan data sekender diambil dari data tertulis berupa laporan dan jurnal.

\section{HASIL PENELITIAN DAN PEMBAHASAN}

\section{Analisis Data}

Analisis data dilakukan dalam dua tahap yaitu dengan pengujian prasyarat analisis dan tahap berikutnya adalah analisis lanjut sebelum dilaksanakan pengujian hipotesis.

\section{Uji Validitas}

Uji validitas digunakan untuk mengetahui kevalidan atau kesesuaian kuesioner yang digunakan peneliti dalam mengukur dan memperoleh data penelitian dalam mengukur dan memperoleh data penelitian dari para responden. Kriteria uji validitas adalah sebagai berikut:

a. Jika $\mathrm{r}$ hitung $\geq \mathrm{r}$ tabel (uji 2 sisi dengan sig, 0.05) maka instrumen atau item-item pernyataan berkorelasi signifikan terhadap skor total (dinyatakan Valid).

b) Jika $r$ hitung $\leq \mathrm{r}$ tabel (uji 2 sisi dngan sig, 0.05) maka instrument atau item-item pernyataan berkorelasi signifikan terhadap skor total (dinyatakan tidak valid).

Syarat minimum dianggap butir instrumen valid pada penelitian ini adalah nilai indeks validitasnya memiliki $r$ hitung $>r$ tabel dimana cara mencari nilai $r$ tabel dengan $N=55$ pada signifikansi 5\% pada distribusi nilai $r$ tabel statistik, maka diperoleh nilai $r$ tabel sebesar 0,266 , jadi $r$ hitung $>0,266$ atau dengan melihat nilai Signifikansi $(\mathrm{Sig})<0,05$, sebagaimana dapat dilihat pada tabel-tabel berikut ini:

Tabel 1. Uji Validitas Kemampuan fasilitas labuh 


\begin{tabular}{ccccc}
\hline $\begin{array}{c}\text { No. Item } \\
\text { pernyataan }\end{array}$ & $\begin{array}{c}\mathrm{R} \\
\text { hitung }\end{array}$ & $\begin{array}{c}\mathrm{R} \\
\text { tabel }\end{array}$ & Signifikansi & Keterangan \\
\hline 1 & 0,639 & 0,266 & 0,000 & Valid \\
2 & 0,665 & 0,266 & 0,000 & Valid \\
3 & 0,598 & 0,266 & 0,000 & Valid \\
4 & 0,478 & 0,266 & 0,000 & Valid \\
5 & 0,570 & 0,266 & 0,000 & Valid \\
6 & 0,472 & 0,266 & 0,000 & Valid \\
7 & 0,307 & 0,266 & 0,023 & Valid \\
8 & 0,292 & 0,266 & 0,030 & Valid \\
9 & 0,644 & 0,266 & 0,000 & Valid \\
10 & 0,609 & 0,266 & 0,000 & Valid \\
\hline
\end{tabular}

Sumber: Hasil pengolahan data peneliti, 2020

Tabel 2. Uji Validitas Dukungan pembekalan

\begin{tabular}{ccccc}
\hline $\begin{array}{c}\text { No. Item } \\
\text { pernyataan }\end{array}$ & $\begin{array}{c}\mathrm{R} \\
\text { hitung }\end{array}$ & $\begin{array}{c}\mathrm{R} \\
\text { tabel }\end{array}$ & Signifikansi & Keterangan \\
\hline 1 & 0,418 & 0,200665 & 0,001 & Valid \\
2 & 0,410 & 0,200665 & 0,002 & Valid \\
3 & 0,567 & 0,200665 & 0,000 & Valid \\
4 & 0,551 & 0,200665 & 0,000 & Valid \\
5 & 0,455 & 0,200665 & 0,000 & Valid \\
6 & 0,505 & 0,200665 & 0,000 & Valid \\
7 & 0,790 & 0,200665 & 0,000 & Valid \\
8 & 0,336 & 0,200665 & 0,012 & Valid \\
9 & 0,513 & 0,200665 & 0,000 & Valid \\
10 & 0,326 & 0,200665 & 0,015 & Valid \\
\hline
\end{tabular}

Sumber: Hasil pengolahan data peneliti, 2020

Tabel 3. Uji Validitas Kesiapan operasi di laut Natuna

\begin{tabular}{ccccc}
\hline $\begin{array}{c}\text { No. Item } \\
\text { pernyataan }\end{array}$ & $\begin{array}{c}\mathrm{R} \\
\text { hitung }\end{array}$ & $\begin{array}{c}\mathrm{R} \\
\text { tabel }\end{array}$ & Signifikansi & Keterangan \\
\hline 1 & 0,906 & 0,200665 & 0,000 & Valid \\
2 & 0,807 & 0,200665 & 0,000 & Valid \\
3 & 0,543 & 0,200665 & 0,000 & Valid \\
\hline
\end{tabular}

Sumber: Hasil pengolahan data peneliti, 2020

\section{Uji Reliabilitas}

Uji reliabilitas adalah metode yang digunakan untuk melihat apakah kuisoner memiliki konsistensi jika pengukuran dilakukan dengan kuesioner tersebut dilakukan secara berulang. Untuk mengukur reliabilitas dengan uji statistik Cronbach's Alpha $(\alpha)$. Suatu variabel dikatakan reliabel jika memberikan nilai $\alpha>0,60$. Hasil dapat dilihat pada tabel berikut ini:

Tabel 4. Uji Reliabilitas 


\begin{tabular}{clccc}
\hline No & \multicolumn{1}{c}{ Pernyataan } & Cronbach's Alpha & Nilai Batas & Keterangan \\
\hline 1 & Kemampuan Fasilitas Labuh & 0,806 & 0,60 & Valid \\
2 & Dukungan Pembekalan & 0,646 & 0,60 & Valid \\
3 & Kesiapan Operasi Kogabwilhan I & 0,620 & 0,60 & Valid \\
\hline
\end{tabular}

Sumber: Hasil pengolahan data peneliti, 2020

\section{Uji Regresi Linier Berganda}

Hasil penelitian menggunakan analisis regresi linear berganda bertujuan untuk mengetahui pengaruh kemampuan fasilitas labuh dan dukungan pembekalan terhadap kesiapan operasi Kogabwilhan I. Perhitungan analisis regresi linear berganda menggunakan bantuan program SPSS 25 diperoleh hasil sebagai berikut:

Tabel 5. Regresi Linier Berganda

\begin{tabular}{|c|c|c|c|c|c|c|}
\hline & \multirow{2}{*}{ Model } & \multicolumn{2}{|c|}{ Unstandardized Coefficients } & \multirow{2}{*}{$\begin{array}{c}\text { Standardized Coefficients } \\
\text { Beta } \\
\end{array}$} & \multirow{2}{*}{$\mathrm{t}$} & \multirow{2}{*}{ Sig. } \\
\hline & & B & Std. Error & & & \\
\hline \multirow[t]{3}{*}{1} & (Constant) & 0,920 & 2,267 & & 0,406 & 0,687 \\
\hline & $\begin{array}{l}\text { Kemampuan } \\
\text { Fasilitas Labuh } \\
\text { (X1) }\end{array}$ & 0,143 & 0,056 & 0,287 & 2,565 & 0,013 \\
\hline & $\begin{array}{l}\text { Dukungan } \\
\text { Pembekalan (X2) }\end{array}$ & 0,316 & 0,072 & 0,489 & 4,369 & 0,000 \\
\hline
\end{tabular}

a. Dependent Variable: Kesiapan Operasi Kogabwilhan I (Y)

Sumber: Hasil pengolahan data peneliti, 2020

Berdasarkan hasil pengolahan data di atas, dapat dijabarkan ke dalam persamaan sebagai berikut:

$\mathrm{Y}=0,920+0,143 \mathrm{X}_{1}+0,316 \mathrm{X} 2+\mathrm{e}$

Hasil regresi linier yang diperoleh dapat diinterpretasikan sebagai berikut: Konstanta (a) adalah 0,920 , berarti apabila variabel bebas kemampuan fasilitas labuh sama dengan nol (0) maka Kesiapan operasi Kogabwilhan I adalah positif sebesar 0,920. Nilai $b_{1}=0,143$ adalah koefisien regresi kemampuan fasilitas labuh bernilai positif, berarti apabila kemampuan fasilitas labuh semakin baik maka dukungan logistik terpadu juga semakin baik. Nilai $b 2=$ 0,316 adalah koefisien regresi dukungan pembekalan bernilai positif, berarti apabila dukungan pembekalan semakin baik maka Kesiapan operasi Kogabwilhan I juga semakin baik.

\section{Pengujian Hipotesis}

Analisis uji t digunakan untuk membuktikan signifikansi pengaruh variabel bebas Kemampuan fasilitas labuh dan Dukungan pembekalan terhadap variabel terikat kesiapan operasi Kogabwilhan I secara parsial. Pengujian dalam penelitian ini menggunakan tingkat signifikansi sebesar $0,05(\alpha=5 \%)$ atau dengan tingkat keyakinan sebesar $0,95 \%$ dengan dasar pengambilan keputusan adalah nilai signifikansi (sig) $<0,05$ maka variabel bebas memiliki pengaruh terhadap variabel terikat. Dimana jika $\mathrm{t}$ hitung $>\mathrm{t}$ tabel maka tidak terdapat pengaruh antara variabel bebas terhadap variabel terikat dan jika $t$ hitung $<\mathrm{t}$ tabel maka terdapat pengaruh antara variabel bebas terhadap variabel terikat.

Hasil uji t pengaruh variabel kemampuan fasilitas labuh terhadap kesiapan operasi Kogabwilhan I diperoleh nilai $\mathrm{t}$ hitung 2,565 > Nilai $\mathrm{t}$ tabel pada tingkat signifikasi 0,05 sebesar 0,200665 dengan sig $(0,013)<0,05$ berarti kemampuan fasilitas labuh berpengaruh positif dan signifikan terhadap kesiapan operasi Kogabwilhan I, sehingga $\mathrm{H}_{1}$ terbukti kebenarannya.

Hasil uji $t$ pengaruh variabel dukungan pembekalan terhadap kesiapan operasi Kogabwilhan I diperoleh nilai t hitung 4,369 > Nilai t tabel pada tingkat signifikasi 0,05 
sebesar 0,200665 dengan sig $(0,000)<0,05$ berarti dukungan pembekalan berpengaruh positif dan signifikan terhadap kesiapan operasi Kogabwilhan I, sehingga $\mathrm{H}_{2}$ terbukti kebenarannya.

\section{Koefisien Korelasi (R) Dan Koefisien Determinasi (R2)}

Koefisien korelasi $(\mathrm{R})$ digunakan untuk mengetahui kuatnya pengaruh antara variabel bebas dan variabel terikat. Semakin besar nilai $\mathrm{R}$ maka semakin tepat model regresi dipakai, karena total variasi dapat menjelaskan variabel terikat sedangkan koefisien determinasi $\left(R^{2}\right)$ dipakai untuk memprediksi seberapa besar kontribusi pengaruh variabel kemampuan fasilitas labuh $\left(\mathrm{X}_{1}\right)$ dan dukungan pembekalan $\left(\mathrm{X}_{2}\right)$ terhadap Kesiapan operasi Kogabwilhan I (Y). Hasil pengolahan data koefisien korelasi dan determinasi menggunakan SPSS 25 dapat dilihat pada tabel berikut:

Tabel 6. Koefisien Korelasi (R) dan Koefisien Determinasi $\left(\mathrm{R}^{2}\right)$

\begin{tabular}{ccccc}
\hline Model & $\mathrm{R}$ & R Square & Adjusted R Square & Std. Error of the Estimate \\
\hline 1 &, $603^{\mathrm{a}}$ & 0,364 & 0,339 & 1,18532
\end{tabular}

a. Predictors: (Constant), DUKUNGAN PEMBEKALAN $\left(\mathrm{X}_{2}\right)$, KEMAMPUAN FASILITAS LABUH $\left(\mathrm{X}_{1}\right)$

Sumber: Hasil pengolahan data peneliti, 2020

Dari pengolahan data pada tabel 6 diatas dapat diperoleh kesimpulan sebagai berikut: Nilai $\mathrm{R}$ sebesar 0,603 atau 60,3\% yang berarti tingkat keeratan hubungan antara variabel Kesiapan operasi di laut Natuna $(\mathrm{Y})$ dengan kemampuan fasilitas labuh $\left(\mathrm{X}_{1}\right)$ dan dukungan pembekalan $\left(\mathrm{X}_{2}\right)$ berdasarkan tabel interpretasi korelasi adalah kuat. Nilai koefisien determinasi $\left(\mathrm{R}^{2}\right)$ sebesar 0,364 , hal ini menunjukkan besarnya proporsi yang dapat dijelaskan oleh variabel independen adalah sebesar $36,4 \%$, sedangkan sisanya $63,6 \%$ dijelaskan oleh variabel lain yang tidak termasuk dalam model penelitian ini.

\section{E. KESIMPULAN DAN SARAN}

\section{Kesimpulan}

Kemampuan fasilitas labuh berpengaruh positif dan signifikan terhadap kesiapan operasi Kogabwilhan I. Nilai koefisien regresi bertanda positif berarti bahwa dengan meningkatnya kemampuan fasilitas labuh semakin baik maka kesiapan operasi Kogabwilhan I juga semakin baik.

Dukungan pembekalan berpengaruh positif dan signifikan terhadap kesiapan operasi Kogabwilhan I. Nilai koefisien regresi bertanda positif berarti bahwa dengan meningkatnya dukungan pembekalan semakin baik maka kesiapan operasi Kogabwilhan I juga semakin baik.

\section{Saran}

Memenuhi DSP organisasi yang ada, khususnya personel yang mempunyai kompetensi di bidang logistik sebagai personel pengawak fasilitas labuh dan dukungan pembekalan guna meningkatkan dukungan logistik di wilayah Natuna dalam mendukung pelaksanaan operasi yang dilaksanakan secara mandiri maupun dibawah Kogabwilhan I.

Melaksanakan peninjauan secara langsung kondisi dilapangan, segera melaksanakan perbaikan sarana dan prasarana yang sudah ada serta penambahan sarana dan prasarana yang belum ada baik fasilitas labuh maupun dukungan pembekalan guna meningkatkan dukungan logistik terpadu di wilayah Natuna dalam rangka mendukung kesiapan operasi Kogabwilhan I

\section{DAFTAR PUSTAKA}

Ahmad Tanzah, 2011, Metode Penelitian Praktis, Yogyakarta: Teras.

A. Muri Yusuf, 2016, Metode Penelitian Kuantitatif, Kualitatif dan Penelitian Gabungan, Jakarta:

Pranada Media Group. 
Benjamin S Blanchard, 1997, Logistics Engineering and Management Fifth Edition.

Cardoso Gomes, Faustino. 2000. Manajemen Sumber Daya Manusia. Yogyakarta.

Eccles, Henry E, 1959, Logistics in The National Defence, Pennsylvania: The Stackpole Company Harrisburg.

Sutrisno Edy, 2011, Manajemen Sumber Daya Manusia, Cet ke-3, Jakarta: Kencana

Hasan M. Iqbal, 2002, Pokok-Pokok Metodologi Penelitian dan Aplikasinya, Bogor: Ghalia Indonesia

Iskandar, 2009, Metodologi Penelitian Pendidikan dan Sosial, (Kuantitatif dan Kualitatif), Jakarta: GP Press.

James V. Jones, 1994, Integrated Logistics Support Handbook 2nd, California: McGraw-Hill, Inc Ken Booth, 1977, Navies and Foreign Policy, New York.

Muthis, Robert L, \& Jackson, John H, 2006, Human Resource Management. 